\title{
Recognition and Disrespect: \\ Lordship and Bondage in Hegel's \\ Phenomenology of Spirit
}

\section{Steffen K. Herrmann}

With regard to the contemporary discussion of recognition and disrespect in social philosophy, this chapter argues that Hegel is not only a seminal 'theorist of recognition,' but also a sophisticated 'theorist of disrespect.' By means of the relationship of lord and bondsman as developed in the Phenomenology of Spirit it is shown that for Hegel the emergence of recognition not only involves freedom and autonomy but can also result in dependency and asymmetry. Building on this assumption, the paper pursues a threefold aim: first, to show, through a reconstruction of Hegel's thoughts on the development of self-consciousness, that a successful form of subjectivation is only possible when a subject can actualize itself in so called 'egalitarian' and 'differential' acts of recognition. The second part aims at a re-reading of Hegel's thinking of the lord/bondsman-relationship. In opposition to the classic 'heroic reading' of this relationship, I make the case for a 'subaltern reading,' arguing that Hegel presents in the figure of the bondsman a form of asymmetric recognition, in which the subject is bound to those conditions that hold it in disrespect. Finally, the third part aims at a reinterpretation of Hegel's thought from the perspective of disresprect in order to show that the other side of Hegel's theory of recognition forms a theory of symbolic vulnerability. Starting from other side of Hegel's theory of recognition forms a theory of symbolic vulnerability. Starting from
this theory one can understand the paradoxical dynamic of disrespect that leads subjects to identify this theory one can understand the parado
with the rations that subjugate them.

One of the most famous relationships of subordination in the history of philosophy is certainly the relationship of lord and bondsman as developed by Hegel in the Phenomenology of Spirit. First and foremost due to Alexandre Kojève's influential commentary from the 1930 s, this relation was regarded for a long time as the core of Hegel's theory of recognition. Mediated by Kojève's interpretation, the figures of lord and bondsman became a characteristic motif of twentieth century French social philosophy. Whether in the writings of JeanPaul Sartre, as the relation of the gaze; in Jacques Lacan, as the imaginary transference relation; or in Frantz Fanon, as the relation between colonisers and the colonised - wherever intersubjective tensions were the object of theoretical reflection, the model of lord and bondsman was regarded as a key to deciphering the real nature of such conflicts: a struggle for recognition, in which it is not so much the physical but rather the social life of the participants that is at stake.

More recently, an influential strand of the reception of Hegel has proposed that the Phenomenology, and with it, the lord/bondsman-relationship, already represents a first stage of decline in Hegel's theory of recognition. In particu-

'For a broad survey of the French reception of Hegel, see Roth 1988. The special influence of
Kojève's Hegel interpretation on French philosophy is treated in Descombes 1980; as well as by Kojève's Hegel
Butler 1987. 
lar, the younger representatives of critical theory, Jürgen Habermas and Axel Honneth, have argued that in the Phenomenology, the crucial point of Hegel's theory of recognition has already been abandoned. Honneth names three reasons for this: first, a strong intersubjective concept of human identity is subordinated here to a developmental logic of consciousness; second, the historically productive role of the struggle for recognition is not taken into account sufficiently; and third, there is no productive differentiation between different levels of recognition (cf. Honneth 1995, 62f.). ${ }^{2}$

In contrast to this recent approach to Hegel, I would like to argue in this essay for a 'Return to the Phenomenology!' by taking up the strand of the French reading of Hegel that sees a special social theoretical potential in exactly this work. In my opinion, two reasons speak for such a return. First, Hegel shows us here more clearly than anywhere else the extent to which the development of subjectivity is intimately connected with the achievement of recognition. I would thus like to argue that the Phenomenology represents not a theoretical flattening, but rather a theoretical deepening of Hegel's thought insofar as it makes explicit that the subject's dependency on recognition is an existential matter. Further, I see a return to the Phenomenology justified by the fact that Hegel here for the first time lets the struggle for recognition lead to the relation of lordship and bondage. This allows him to connect the development of recognition not merely to the development of freedom and equality, but rather to show that the dependency of recognition must also be understood as the condition of inequality and asymmetry. Insofar as Hegel explores the precarious nature of intersubjective relations of dependency through the lord/bondsman-relationship, he proves himself not only to be a subtle 'theorist of recognition' but also just as much a sophisticated 'theorist of disrespect."

Starting from this diagnosis, my essay pursues a threefold aim. First, through a reconstruction of Hegel's thinking of the development of self-consciousness, I would like to show that recognition by the other is of existential significance for a subject. With this it will become clear that a successful form of self-actualization is only possible if a subject knows itself as recognized both as an equal and as an individual. Only in the framework of so called 'egalitarian' and 'differential' acts of recognition, so I will argue, is a subject brought to life (I). The second part of my considerations aims to re-read Hegel's thinking of the

${ }^{2}$ Similar arguments were previously made by Jurgen Habermas, who speaks of how the "communicative reason" that emerges in Hegel's early writings is already subordinated in the Phenomenology to the framework of his philosophy of the subject (Habermas 1990, 31 and 41). For the impact of his position in the French languge literature, see Riceur 2005, 173 and 186. Representative of the this position in the French language literature, see Ricœur 2005, 173 and 186. Representative of the English language literature

A re-reading in this vein has been recently undertaken by Patchen Markell: "Hegel's account suggests that the pursuit of recognition itself may be implicated in the formation and maintenance of unjust relations of social power" (Markell 2003, 112). In reference to the "unhappy consciousness' that develops out of the lord/bondsman-relationship, Judith Butler has also attempted to show with an alternative reading how Hegel connects recognition and disrespect in his thought (Butler 1997). lord/bondsman-relationship. In opposition to the classic 'heroic reading,' I would like to put forward a 'subaltern reading' that makes explicit the manner in which Hegel's use of the figure of the bondsman reveals a form of asymmetrical recognition, in which the subject is bound to the conditions that at the same time hold it in disrespect (II). Following this, the third part of my reading aims at a reinterpretation of Hegel's theory of subjectivity from the perspective of disrespect. Here I would like to make it clear that the other side of Hegel's theory of recognition forms a theory of symbolic vulnerability. Starting from this theory, we can understand the paradoxical dynamic of disrespect that forces the bondsman to identify with the relations that hold him in subjugation (III).

\section{From Theoretical to Ethical Self-Consciousness}

My reconstruction of the development of self-consciousness starts from the idea that Hegel's often convoluted and obscure argumentation can be relatively clearly structured into four steps. In a first step, Hegel lays out the problem that he sees contemporary theories of self-consciousness confronted with. In three further steps, which go from practical, through social to ethical self-consciousness, he develops an alternative conception of the intersubjective character of self-consciousness. With few, but nevertheless strong brush strokes, I would like to give a sketch of each of these steps.

Before we begin, we need to get grip on what the expression self-consciousness means for Hegel. Hegel does not give an explicit definition anywhere, but it is clear that, following the Cartesian-Kantian tradition, he defines a reflexive recourse of consciousness upon itself as "self-consciousness" - so firstly by this expression a kind of self-relation is designated. For Hegel, this self-relation is not an indifferent relation, but is, rather, based on a certain kind of self-interest, and is founded upon the question, "who am I?". And insofar as self-consciousness attempts to answer this question, it develops a specific conception of who it is and what constitutes its existence - we can thus speak of it as developing a specific self-conception. The idea of self-consciousness, with which Hegel then operates, thus signifies a tripartite relation of self-relation, self-interest, and self-conception. ${ }^{4}$ With this explication of the idea of self-consciousness, we can now sketch the problem that Hegel sees self-consciousness as initially confronted with

Robert Brandom makes a very similar tripartite determination of the concept of self-consciousIIess and emphasizes that what constitues the essence of a self-conscious being is dependent upon which attributes are fundamental for it. For Brandom self-consciousness is charecterized above through its capacity for "self-transformation" He summed up this insight in the often abe all ment that "csentilly self-conscious beings do not have (Brandom $2(1) 7,128$ 
Hegel begins his discussion of self-consciousness with a critique of Descartes' and Kant's rationalist positions. According to Hegel, the key characteristic of such positions is that the tripartite structure of self-consciousness is interpreted as a theoretical relation. That is, in this tradition the answer to the question "who am I?" is found through a reflection in thought. Following Hegel, this position can be summarized by the term 'theoretical self-consciousness.' The deficiency of this form of self-consciousness consists in the fact that its conception of self is a mere abstract and universal understanding; it has existence only in the thought of the subject and is purely ideal. As long as this remains the case, the subject cannot achieve any self-certainty. In other words, it suffers from a "lack of certainty." As long as the subject's self-conception exists only theoretically, self-consciousness cannot say with certainty who it is.

For Hegel, the deficiency of theoretical self-consciousness can only be negated once self-consciousness gives itself the "form of being" (I05). ${ }^{6}$ This means that the initially abstract and universal moment in theoretical self-consciousness undergoes a process of objectification and in this process must prove itself to be true. For Hegel, the subject's conception of self can only become certain through practical actions in the world. This practical action is the very point from which Hegel begins the story of the subject's experience, in order to show how the path of self-consciousness approaches step by step a condition that he calls 'being in and for itself,' which simply means that the selfconception of self-consciousness has been able to objectify itself successfully in the world. To put it more simply: what for Hegel should be achieved in the practical intercourse with the world is self-certainty. But to reach this point, theoretical self-consciousness has a long way to go. It has to take three steps to achieve "the truth of self-certainty," as the chapter on self-consciousness is titled.

(i) Practical self-consciousness: The first stage in the subject's path of development is practical self-consciousness. The logic of this stage is determined by the interplay of two elements: first, what the subject believes itself to be, and second, the practical activity through which it seeks to confirm this belief. The first element, self-conception, which the subject develops in response to its inherent question, "who am I?," represents a kind of radicalized transcendental idealism. The subject initially believes to be the only independently existing being. That is, it starts from the assumption that it has an absolute freedom, on the basis of which it creates the world out of itself. ${ }^{7}$ This self-conception

'In the Encyclopedia of Philosophical Sciences Hegel makes it clear that this lack has a positive "counter-concept, when he speaks of self-consciousness as the "impulse to realise its implicit nacoure lure, hy giving its abstract self-awareness content and objectivity" (Hegel 1971 [1830], §425). In Taylor 1975, 150).

"All page numbers in parentheses refer to the Phenomenology of Spirir (I legel 1977 | 1807 ).

${ }^{7}$ Here I am taking up the expression "abstract Freedom," which Hegel uses in the Eincyclopraedia to signify self-conception (Hegel 197||$|1830|, \S 424$ ). With this liomuli he characterizes a radicalized can best be summarized in the statement, "I am everything, the world is nothing." "The second important element is the practical activity through which the subject attempts to actualize its self-conception. Hegel determines this as 'desire,' which refers to the animal desire of recreation. It is through the consumption of objects that practical self-consciousness can exhibit independency, insofar as it annihilates all living things around itself that could also claim to have this status. Through the satiation of desire, therefore, not only is the subject's hunger satisfied, but also its self-conception confirmed. And in the feeling of satiety this self-conception becomes objective for the first time. Hegel thus speaks of an "unalloyed feeling of self" (118) to make explicit that through the process of satisfying needs, practical self-consciousness comes for the first time to a form of self-certainty.

For Hegel, the certainty achieved through desire does not last long; only as long as the feeling of satiety continues. Hence, already after a short time a new object must be consumed in order to reconstitute certainty. But insofar as this certainty can only be of a temporary duration, practical consciousness is caught in a restless process of self-assurance that can never come to an end. The transitory and inconstant nature of the feeling of satiety does not hold the subject captive to a circular process, but rather leads it to the insight that its self-conception was mistaken. Starting from the premise that it is the only independent being, in the restless consumption of things the subject must gain the insight that these things are also independent insofar as it can devour the individual specimen, but not the species as such. Thus the subject comes to see that it must accept that there are other independent entities besides itself. Because this insight, however, undermines the self-conception of the subject in its fundaments, it must travel what Hegel calls the "way of despair" (49). Stripped of its self-conception, the subject has to pose the question, "who am I?," anew.

(ii) Social self-consciousness: For Hegel, the moment the subject begins to develop a new self-conception, the transition to a second stage of development lakes place. It is clear here that the new self-conception can no longer claim to possess absolute freedom, insofar as the subject has realized that it is just one independent being among others. Because the subject wishes to depart from its original self-conception as little as possible, it comes to an insight that can be paraphrased as follows: "If I have to recognise other independent objects alongside myself, then these objects have at least to comply to my freedom." The

"intian idealism as expressed in Fichte's dictum, "All reality is an act of the self," or in Berkeley's "esse est percipi." On I legel's relation to Fichte and Kant cf. Redding 2009, 95.

"rederick Neuhouser reformulates in a similar way self-consciousness's claim with the wor

IIII cverything (everything that counts), and my objects are nothing" (Neuhouser 2009, 44).

Hans-Georg Gadamer speaks of the immediate "vital certainty" that desire attains through the consumption of objects ((jadamer 1976,6(0)). For fiurllier important points on desire and its failIfre see Neuhouscr 1986 and II onneth 20 (i)k 
subject thus no longer claims to be the only independent being, but it does claim to be the highest ranking of all independent beings. Therefore the self-conception of possessing a superior freedom now takes the place of the claim to absolute freedom. Whilst for Hegel, the subject's self-conception in the first stage represented a radicalized version of Kant's transcendental idealism, the self-conception of this new stage represents a radicalized version of Hobbes' theory of natural law, insofar as the subject of natural law, who Hobbes has in mind, presumes that it has a "right to every thing" (Hobbes 1996 [1651], 87). ${ }^{10}$ With this phrase, Hobbes signifies exactly what I call from Hegel's perspective "superior freedom," namely, the claim to be able to have free reign over one's environment without external limitations on action.

An important characteristic of the second stage of the subject's development is that now other subjects come into play as well. To the extent that the subject realizes that other independent entities exist alongside it, it begins to differentiate between them and hence to distinguish between the object and the other. "While in the first stage the subject orients itself for its self-assurance toward an undifferentiated outside, in the second stage it orients itself toward an other. This is because the subject has had to learn that the object only provides a temporary form of satisfaction. In contrast, the other seems to promise a more lasting form of satisfaction, because he is, as Hegel says, capable of self negation (Pinkard 1994, 52). This capacity of self-negation means at first nothing more than that the other human being is capable of its own subjugation, through which he or she, as opposed to the object, can provide a continuous form of acknowledgement. What characterizes the acknowledgement received from other human beings is also the fact that while the subject can only be acknowledged in its objectivity by the object because the object has no 'notion,' so to speak, of subjectivity, the other can grasp the subject in its essence. Because only another human being is capable of understanding what the essence of a subject is, only he or she can affirm the subject as a subject. This special form of acknowledgement, which only the other can provide, is what Hegel calls recognition. After the failure of desire, the subject, whose story of experience we are following, has thus finally won a new conception of the practical activity through which it can achieve self-certainty.

It is the praxis of recognition and no longer the praxis of animal recreation that aids the subject in the second stage of its attempt to reach certainty of its self-conception. We can thus name this form of self-consciousness 'social self-

${ }^{10}$ Hegel's recourse to Hobbes is discussed extensively in Siep 1974, Tamineaux 1985 and Peperzak 1995

11 Judith Butler points out that the other is not a new element in the subject's universe, but rather Judith Butler points out that the other is not a new element in the subject's universe, but rather that an already existing phe Other must be understood as emergence into explicit reality which has hitherto remained an implicit or nascent being. Before its actual appearance, the Other remains opaque, but not for that reason without reality. Coming into existence - or explicit appearance - is never, for Hegel, a creation
ex nihilo, but is, rather, a moment in the development of a Concept" (Butler 1987, 47). consciousness.' With this form of self-consciousness the subject comes to realize that it is dependent upon recognition by the other. Only if the other acknowledges the subject's self-conception in actions and words it is brough into the world. The subject's existence is therefore essentially a social existence, insofar as it can only be certain of its existence through its recognition by others. In this context Hegel speaks of how in the encounter with the other self-consciousness ends up 'out of itself,' which means that from now on it can only find itself in an exteriority: the subject comes to be only if it is outside with the other. This decentring, however, is experienced as a threat because the subject is herein confronted with the loss of the power of its selfdetermination. Self-consciousness's 'being out of itself' should therefore not be read as a purely logical category, but must also be understood as the reflection of an emotional state as the German term 'außer-sich-sein' implies: the subject's loss of its sovereignty makes it angry and aggressive. ${ }^{12}$ The other, on which the subject knows itself to be dependent, is at the same time the object of fear, anger, and aggression. This basic ambivalence forms the background for understanding the concrete encounter with another subject from the perspective of the experiencing subject.

The practical demand for recognition leads the subject at first into a conflict with the other. As the other has the same self-conception, both subjects find themselves in a situation in which their respective self-conceptions are mutually exclusive. And insofar as neither participant wishes to voluntarily give up its self-conception, a conflict which culminates in a life and death struggle develops out of this contradiction. Hegel's famous "struggle for recognition," leads into the equally well-known relation of "lordship and bondage," which I will later go into in detail, in which the bondsman gives up his self-conception to the benefit of the lord. Through this, a first form of sociality emerges, in which the participants are capable of living together in a community. ${ }^{13} \mathrm{Ad}-$ mittedly, for Hegel this is only of temporary durability insofar as this community is based on "a recognition that is one-sided and unequal" (116) which leaves both participants unsatisfied. On the one hand we have the bondsman, who suffers under the inferior self-conception forced upon him, and on the other hand the lord, who after a while comes to the realization that his superior self-conception is extremely unstable. This is because he actually despises the bondsman on account of his inferior self-conception and thus canno value the recognition he receives from him. The lord thus faces the problem that the recognition he receives comes from someone who he holds for not worthy of recognition. Through this he finds himself in an "existential im-

Julith Butler has emphasized this point: "That self-consciousness can find its own essential prininle cultudied clsewhere appears as a frightening and even angering experience" (Butler 1987. 48).

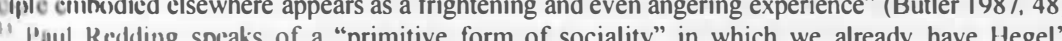
' 
passe" (Kojève 1980, 46). We have now reached the point at which both subjects we have met up to now have failed at their attempt to achieve certainty of their superior freedom. Thus both subjects have to question their identity once again.

(iii) Ethical self-consciousness: To understand how the subject continues its process of experience after the failure of the lord/bondsman-relationship, one must venture a jump to the chapter on the ethical life in the Phenomenology. Here self-consciousness gains the insight that the freedom it seeks can only be a social freedom. This means that because of its experiences it cannot make a claim to freedom without acknowledging this claim on the part of others. Selfconsciousness is thus ready to restrict its unrestrained freedom, because it realizes that it can only achieve certainty when it is recognized by a free other, which presupposes that it also recognizes the freedom of the other. The claim to social freedom thus contains "less" than the claim to superior freedom, because here the subject's scope of possible agency is reduced for the benefit of others. In another sense, however, it actually contains "more," as the subject who claims social freedom - unlike in the case of superior freedom - can be reassured of this right in the face of others. Whilst this existed only in an abstract idea that was confirmed by no one, the social freedom of the subject can be seen in the other insofar as he or she recognizes this freedom. Self-consciousness thus realizes that actual freedom can only exist under conditions of mutual recognition. The subject's new self-conception on this level can be formulated thus: 'My freedom can only be the freedom of all.' The failure of the social conception of self has hence led to a form of self-relation that, with Hegel, we can call 'ethical self-consciousness.'

After explaining the character of the subject's new self-conception, Hegel then shows us how the practices through which the subject gives this selfconception a social existence are structured. Hegel differentiates between two forms of acts of recognition at work in the ethical community. On the one hand there is the "human law" of the community and on the other hand the "divine law" of the family (267 and 278). ${ }^{14}$ For Hegel, in the human law, those forms of recognition emerge that acknowledge the individual in his or her universality. When subjects follow the same law they oblige themselves not only to fulfil the same duties, but also recognize the same rights for all. It can be said that 'All are equal before the law' in the sense that every subject is granted the

it Of course, in this section Hegel discusses, using Sophocles' Antigone as an example, a first and insufficient form of the ethical life in which these two laws are still in conflict with each other. Even if for Hegel the ancient form of the ethicat is doomed to failure, it stll contain in Even if for already both of those principles that in the further course (of the experience of consciousness) are reconciled. Frederick Neuhouser has pointed out that this reconciliation represents the crucia point of Hegel's project. "The values of individuality and social membership are not to be though of as competing or mutually exclusive ideals. In fact, each of these ideals, properly understood, can be realized only in conjunction with the other" (Neuhouser 2000, 15). status of a legal person. The form of recognition expressed in human law can thus be called 'egalitarian recognition,' which, ignoring individual idiosyncrasies, acknowledges the subjects in those respects that are common to all. We can name this form of recognition respect. In divine law, which Hegel sees at work in the family, the situation is just the opposite. For Hegel, the family is the site in which the particularities of a subject find recognition. In contrast to the public sphere of the political community, which is so extensive that the members remain for the most part strangers, the private space of the family is still small enough to allow the members to know each other in their particular attributes and capacities. In contrast to human law, the kind of recognition granted by the law of the family concerns not the individual in his or her universality but rather the individual in his or her particularity. As every individual is affirmed here in his or her singularity, the structure of recognition consists no longer primarily in the emphasis of equality between the participants, but in exposing the differences between them. Hence it is not equality but rather difference that is distinctive for divine law, which is why in this case we can also speak of a 'differential recognition' or a valuation of the individual for his or her individual particularities.

On the basis of these two scales of recognition practices, ethical self-consciousness enters the sphere that Hegel calls "Spirit." This basically means that self-consciousness can find true certainty on this level. The subject can reach that condition of 'being in and for itself' that Hegel proposed at the beginning as the goal of the process of self-development. We are now justified in saying, "Self-consciousness exists in and for itself when, and by the fact, it so exists for another; that is, it exists only in being acknowledged" (III). Recognition, as we have seen, must be understood here in a double sense of an egalitarian and a differential recognition. Only through this double action does the subject find itself again in the state that Hegel described with the famous expression of the "I' that is 'We' and 'We' that is 'I"' $(110)$. In the ethical community, the deficiency with which the story of the development of the subject began has been superseded. The self-conception of self-consciousness is no longer abstract and universal; rather, it has objectified itself in the world, so that the subject knows that it is conserved in the world in its particularity. In other words, self-consciousness has reached the condition of self-certainty.

\footnotetext{
19. The two sides I have set out here have also been identified as the central components of the ethical lifie by Robert Pippin when he emphasises that freedom can only be reached through the interplay of universal and individual recognition: "That goal would be: to be able to show (i) that one could be a free subject only in being recognized as one; (ii) that what that would involve is being concretely recognized as, really taken as, one among many, and that (iii) the concrete or mediated unire of such recognition must mean in modern life being loved (or being able to be loved) as a person, al distinct, entitled individual !. I" (I'ippin 2008, 209).
} 
Now that we have followed the process of the development of self-consciousness through its various shapes, I would like to sum up three central points that Hegel has made explicit for us in this process: (i) The subject is driven by a lack of self-certainty, which can only be satisfied by recognition by others. It can only come to itself via the detour of alienation; it finds itself first and to begin with outside of itself. (ii) Hegel provides us at the same time with two normative criteria that he regards as necessary prerequisites for a successful selfactualization of self-consciousness. It must know itself to be an equal among equals in its belonging to a community. And at the same time it must know itself in its particularity, through which it differs from other members of the community. Only through the double action of respect and valuation, egalitarian and differential recognition, can a subject actualize itself. (iii) Finally, Hegel tries to show us that a subject can only achieve the actualization of its self-conception in accord with others. Only in relations of mutual and symmetrical recognition can the subject achieve that form of self-certainty, the finding of which is for Hegel the original driving force of self-consciousness.

While Hegel formulates in his first two theses basic insights into the normative character of intersubjective relations, I would like to show that his third thesis needs to be reformulated to meet the challenges of a critical social philosophy. While Hegel wanted to show within a specific historical constellation that relations of recognition can only be actualized under conditions of mutual symmetrical equality and thus - at least in his youth - made the theory of recognition a critique of the existing state of affairs, today his theory remains an instrument of critique because it can help to show how relations of recognition contain a one-sided dependency through which asymmetric social relations are established and supported. In other words, recognition in its essence does not fundamentally tend toward mutual symmetry, but is rather radically asymmetric. Instead of being a motor of emancipatory progress, recognition can in fact also cause relations of inequality. In what follows I would like to show that this insight can already be found in Hegel's text, if we undertake a reading of the struggle for recognition and the relation of lordship and bondage that differs from a conventional reading.

\section{Lordship and Bondage: Recognition and Asymmetry}

The project of an alternative reading of Hegel's theory of recognition takes up a French line of Hegel-interpretation that starts from Alexandre Kojève's wellknown reading. Kojève's lectures on the Phenomenology of Spirit, held between 1933 and 1939 at the Ecole Pratique des Hautes Etudes in Paris, influenced a whole generation of French intellectuals. ${ }^{16}$ This is in part because he

${ }^{16}$ Kojève's students included, among others, Jacques L acan, Emmanucl 1.evinus, Maurice MerlealuPonty, and Georges Bataille. Although the opporsite is often asserted, Jemn-l'aul Surtre dicl not was able to communicate to his contemporaries a new fascination for the seemingly dry idiom of Hegel's philosophy. Above all, there were two themes that made up the special attraction of Kojève's reading. On the one hand, his interpretation of Hegel's theory of self-consciousness takes as its starting poin a 'desire for recognition,' which fundamentally distinguishes human existence from animal existence. ${ }^{17}$ In contrast to the latter, human desire is not directed toward an object, but toward another desire. The desire for recognition is thus essentially a desire to be desired by another. This point defines what has been called Kojève's 'anthropological reading' of Hegel. On the other hand, Kojève places the lord/bondsman-relationship at the centre of his interpretation. Between these two protagonists he sees not merely an internal logic of the development of self-consciousness at work, but a universal dialectic, which constitutes the model for the further course of human history as a whole. ${ }^{18}$ This moment defines what is called Kojève's 'historico-teleological reading' of Hegel.

While many of Kojève's well-known students appropriated the anthropological reading of Hegel and made the theme of recognition a central point of reference in their thought, at the same time for many others the theme of a continual historical process of progress became untenable, especially under the impact of National Socialism. As a consequence, the theme of lordship and bondage was separated from the historical teleological context and increasingly interpreted as a social ontological relation. Above all, the works of Jean-Paul Sartre and Jacques Lacan stimulated this transformation. For both thinkers, the lord/bondsman-relationship represents not so much the motor of history, but rather the foundation of every intersubjective encounter. In other words, for both Sartre and Lacan our social relationships are always already structured according to the asymmetric model of lordship and bondage. Sartre makes this explicit when in Being and Nothingness he states: "But this slavery is not a historical result [...] of a life in the abstract form of consciousness. I am a slave to the degree that my being is dependent at the centre of a freedom which is not mine and which is the very condition of my being" (Sartre 2002 [1943], 358). And Lacan concludes his well-known paper on the mirror stage with the comment that we are essentially bound to the other through an "imaginary servitude" (Lacan 2002 [1949], 9). In the tradition of such a social ontological interpretation of the lord/bondsman-relationship, I would like to develop in what follows a reading that differs from the conventional interpretation of this

iltend the lectures, but did know the scripts of Kojève's lectures. For a list of the seminar participaunts see Roth 1988, 225

17 hojève stutes in reference to this, "In other words, all human, anthropogenetic Desire - the desire that generates Self-Consiouciess, the human reality - is, finally, a fiunction of the desire for "ire that generates Serf-Consionciess,

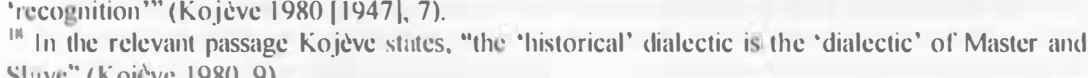
Slive" (Kojève 1980), 9) 
relationship insofar as it brings to the foreground the motif of a one-sided asymmetrical dependency of recognition. ${ }^{19}$ Before I introduce this 'subaltern reading,' I would like to show why in my view the classic 'heroic reading' of this relationship seems to miss a crucial point of Hegel's argument.

(i) The heroic reading: This reading starts from the premise that the lord/ bondsman-relationship is constituted by a fear of death, as a result of which one of the participants voluntarily subjugates himself to the other. Before the struggle comes to its fatal end, it is interrupted because one of the subjects fears risking its life. Thus instead of putting his life on the line, he prefers to subjugate himself and become the bondsman of the other. The price he pays for saving his life is the renunciation of his self-conception of possessing a superior freedom. In this reading, the lord is the real hero of the story: as opposed to the fearful and weak-willed bondsman, he proves his steadfastness in the face of death. He is the one who for the sake of his self-conception risks his life and does not let himself be intimidated by his imminent death. It is this perseverance that in the history of philosophy has consistently elicited admiration for the lord. Following the motto, 'All or Nothing!', he would rather die a hero than lose what he is fighting for.

Admittedly, the heroic reading does have in an attenuated form a quite plausible connection to everyday practical experience (Brandom 2007, 131). Insofar as in everyday life we often have particular respect for those who stand by their conception of self even in situations where they have to accept grave disadvantages for this - for example, when someone leaves a well-paid position for moral reasons. In contrast, we have little regard for someone who at the first sign of difficulty throws his or her self-conception overboard - for instance when someone is ready to suspend important moral convictions for the sake of gratification. But even if the heroic reading in such cases seems to find a certain confirmation in real life situations, it leaves the conditions that constitute the scope of possible action unconsidered, in order to concentrate exclusively on the actors as strong-willed authors of their actions. Above all, however, I think it does not do justice to Hegel's project, because by focussing on the heroic lord it overemphasizes the potential for autonomous self-control and thus loses sight of the existential significance of recognition by others.

There are three objections that I think can be brought against the heroic reading. Firstly, one needs to keep in mind that for Hegel, the lord, who appears here as the archetype of successful self-actualization, later becomes the figure who remains arrested in his development. This suggests that the actual

\footnotetext{
${ }^{19}$ Patchen Markell also offers an alternative reading of the lord/bondsman-relationship. In contras from the figure of he lord and attempts to show that have to be essertilly cond and a
}

developmental leap that is executed in the struggle should not be sought on the side of the lord, but on the side of the bondsman. Secondly, the heroic reading seems to me to abbreviate the struggle for recognition because it overlooks the fact that for Hegel in the Phenomenology this struggle is carried out until the point of death, while in earlier versions it is interrupted before this point. Here the life-and-death struggle remains for the participants not a mere dark presentiment; it becomes a bitter reality. And as a consequence, thirdly, what is further overlooked is that the subject, whose story of experience we follow, at first survives the struggle as a victor, before it decides to subjugate itself to the other as its bondsman. Only when one takes these three points into consideration, does it become sufficiently clear why in the Phenomenology Hegel has the life-and-death struggle lead to the famous relation of lordship and bondage. For indeed, instead of, as in earlier drafts, going directly over to the insight that recognition is only possible between equals, in the Phenomenology, Hegel explores the possibility of recognition being the cause of inequality and one-sided dependency.

(ii) The subaltern reading: This reading starts from the premise that self-consciousness, the development of which we follow in the Phenomenology, is that which survives the life-and-death struggle by killing the other. This reading can claim to be a 'close reading' insofar as Hegel himself explicitly states that the experience of self-consciousness extends through the life-and-death struggle to the point at which it has "survived the struggle" $(114) .^{20}$ If one approaches the interpretation of the struggle from this perspective, the focus is displaced from the question of which of the participants has risked their life to the question of what the survival of the struggle means for the subject. And Hegel's answer is unequivocal: victory in the struggle is for self-consciousness not so much a sign of its honour, as rather the cause for its failure. Similarly to the case of animal desire, the subject here must come to realize that to the extent that it destroys its counterpart, the certainty of its own self-conception, which actually is supposed to emerge from this, is called into question. The "trial by death," as Hegel observes, "does away with the truth which was supposed to issue from it, and so, too, with the certainty of self generally" (114). In the case of the life-and-death struggle, the reason for this failure lies simply in the fact that without the other, who it has killed, the subject is no longer capable of achieving acknowledgement of its self-conception. This is because through the killing of the other, the subject has simultaneously destroyed the very condition of the possibility of self-certainty. The struggle thus ends unsatisfactorily

211 In this passage and in the entire paragraph that follows, which is dedicated to the failure of the struggle, Ilegel neither uses the subjunctive nor the perspective of the philosophical observer, but
rnther describes the experiential perspective of self-consciousness. This is underscored by the rinther describes the experiential perspective of self-consciousness. This is underscored by the
opening sentenee of the next paragraph: "In Ihis experience, self-eonsciousness learns that life is as cessential to it as pure self-consciousness" (11 15 ) 
for the surviving self-consciousness: the certainty of self, which should have been gained here, is not achieved.

The subject, who has survived the life-and-death struggle as victor, now draws an important conclusion from its failure. Hegel formulates this with the words, "In this experience, self-consciousness learns that life is as essential to it as pure self-consciousness" (115). As in the other stages, the subject realizes that it can only achieve self-certainty if it develops a different form of selfconception. The new conception that it reaches now consists in the insight that it can only be certain of itself if both its own life and the life of the other are preserved. The surviving subject thus realizes that it must protect life if it wishes to actualize itself as self-consciousness. This insight represents the decisive turning point for the further course of the story: its consequence is that the subject at the next encounter with another human no longer seeks conflict but rather a different resolution. This resolution will consist, as Hegels teaches us, in the confirmation of the superior freedom of the other and the acknowledgement of him as his lord. The reason for this 'self-chosen bondage' is that the subject can expect from this subjugation a reliable self-conception in his life. ${ }^{21}$ That is because to the extent that the bondsman confirms the lord, he can assume that the lord will acknowledge him. The subject, whose process of experience we are following, thereby exchanges its initial self-conception of superior freedom (which it realises cannot be actualized) for a self-conception of inferior freedom, because it can at least reach certainty about this. The bondsman is thus ready to subjugate himself, because in exchange he receives at least as much recognition as he requires to reach a minimal form of selfcertainty.

In the reading proposed here, the bondsman embodies the figure that shows us how existential the desire for self-certainty can be. He realizes that before being incapable of reaching any self-certainty at all, he will rather accept a form of disrespectful recognition to reach with its help at least some form of self-certainty. What Hegel is thus presenting with the figure of the bondsman, one could say, is an 'ontological primacy' of the desire for recognition over the desire to actualize a specific conception of self. As opposed to the heroic reading, which emphasizes the sovereignty of the lord, for the subaltern reading the heteronomy of the bondsman is crucial. It starts from the premise that instead of seeing the transition from the struggle for recognition to the relationship of lordship and bondage as motivated by a heroic form of independence we should rather pay attention to the far-reaching mode of dependency that Hegel shows us in the figure of the bondsman. This dependency can, in certain

\footnotetext{
${ }^{21}$ Paul Redding has pointed out that the bondsman declares himself ready to take on his sub jugation precisely in exchange for a form of self-certainty: "But it is impertant that the bondsman's role has been chosen, rather than simply accepted as 'given.' ... The hondsman his., we might say, commethed himself to his identity in exchange for his life and he holds humself 1 (o) his commitment in his

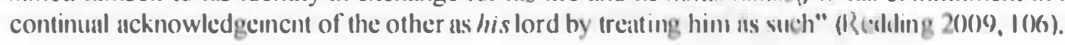

circumstances, go so far as to make the subject accept relations of inequality. Insofar, namely, as the subject accepts its role in such asymmetric relations, it is assured of at least some form of recognition.

A serious objection that can be raised against my reading of the lord/bondsmanrelationship is that such a relation of recognition is necessarily condemned to failure. Hegel himself points out in a central passage that the bondsman's recognition is worthless for the lord, because the lord cannot regard him as an equal. Relations of recognition, it can be argued, contain an emancipatory potential because those privileged in these relations only gain satisfaction to the extent that a mutual symmetrical equality between the actors has been established. ${ }^{22}$ This objection seems to me to be justified insofar as it points out that relations of recognition matter the more they are actualized in mutual symmetric relations. At the same time however, it seems to me that this objection does not hold insofar as it is based on the assumption that unequal relations of recognition are necessarily unsatisfying for those privileged in these relations. One can argue against this assumption on three grounds: first, the distinction introduced earlier between egalitarian and differential recognition shows that an asymmetrical relation of worth can be based on a symmetrical relation of respect. Put more simply, even if the lord despises the bondsman in his concrete conditions of life, he can nevertheless enjoy the respect of the bondsman as long as he regards him as in his essence fundamentally equal to him. Second, this would mean that the lord could gain sufficient recognition through increasing his followers. In this model the lord would reach a satisfactory amount of recognition by multiplying the slight recognition of the bondsman by means of the number of his followers. And third, the recognition that the lord seeks can also come from a third party. Because he has a bondsman, the lord can be recognized by another lord. Kojève has in mind such a resolution of the dual problem of recognition through the involvement of a third party when he writes: "Actually, others recognize the master as master only because he has a slave" (Kojève 1980, 20).

\footnotetext{
"Avishai Margalit describes the failure of the lord quite vividly with the following comparison: "The master's attitude here is similar to that of a soccer team that wants to def eat the rival side decisively but also wants its victory to be recognized as an achievement A crushing victory dectcuses the value of winning since it testilies thit the other side was lics the contradiction - one wints and does not nwimt to trome lime Humilition is intended iime.... Mumilation is intended both (o) prove absolute superiority and to win recognition, whic is a conceptual impossibility" (Murgalit 19)6, 1()96.).
} 


\section{Symbolic Vulnerability and Disrespect}

In the previous section I argued that with the lord/bondsman-relationship Hegel shows us an asymmetrical relation of recognition. I suggested that the bondsman accepts the disrespect towards him because he realizes how existential the recognition by another is for him. After this re-reading of Hegel's text, I would now like to bring to light the outcome contained in this reading. First, I will explain how the struggle for recognition should be read as an occurrence of disrespect. In a second step, I will explain wherein the specific form of symbolic vulnerability provoked by this struggle consists. On this basis, I would like to make clear in a final step which conditions motivate the bondsman to subjugate himself and identify with the bonds that tie him to this subjugation.

(i) Let us begin by recalling what happens in the struggle for recognition. In the vocabulary that resulted from this encounter we can say that the struggle begins with the meeting of two 'lords.' In their self-conceptions these two lords see themselves as beings that possess an unrestricted freedom. Their self-conceptions are constituted along the axis of superiority and inferiority, upon which each assumes to hold a higher position than the other, insofar as each expects the other to subjugate himself to his claim to unrestricted freedom. In the self-conception of the actors there is already a latent tendency of disrespect towards the other. This is expressed in the moment that the two subjects communicate: since by mutually expressing the self-conception of their own superiority, they articulate not simply a neutral evaluation of the situation, but each rather expresses disrespect for the other. Again, in the vocabulary developed from the outcome of the struggle we could say that each of the two lords expresses that he holds the other for a mere bondsman. The expression, "you're nothing but a bondsman!", is understood by each participant as an instance of disrespect, because it is not compatible with its particular self-conception. If we reformulate what happens in the struggle for recognition in this way, then the struggle must be understood at least as an occurrence of mutual disrespect, in the sense that the participants fight with the means of symbolic violence before the struggle escalates to physical violence.

While it seems obvious how physical violence may result in injury, it is not at all clear how symbolic violence may cause harm. While in everyday life one speaks of how an act of disrespect 'hurts,' and we are used to using the concept of injury to describe damage to the material existence of the body, what the concept in this symbolic context might mean has yet to be clarified. In this regard, I think Hegel's theory of self-consciousness provides us with the corresponding vocabulary: his thoughts on the theory of recognition allow us to reformulate the vulnerability called forth through an act of disrespect in the context of a theory of the subject. (ii) What the subject's symbolic vulnerability consists in becomes clear when one looks at the theory of recognition from its other side. For indeed, what Hegel presents from one side as the process of subjectivation is, when looked at from the other side, in fact nothing other than a process of de-subjectivation. Thus, an act of disrespect can be described as harming the process in which the subject gains self-certainty. A central step in this process, as we have seen with the transition from practical to social self-consciousness, is the social existence of the subject. But as this existence only lasts as long as it is continually reproduced through recognition by others, disrespect can be understood as a threatening to dissolve the subject's social existence by means of a refusal to recognize. However, insofar as the self-relation of the subject is first actualized in social existence, how that social existence may be harmed must be understood in a second step as a process in which the self-relation of the subject is at stake. On this second level, harm would no longer represent dissolution but rather a disruption that makes it impossible to build a secure self-relation. Moreover, because the subject's self-relation is harmed by disrespect, in a third step we have before us a form of violence towards the subject's very self-conception. And on this third level, harm would thus mean that the subject comes to doubt whether that which it held to be its truth is really right. It is thereby set back into the state of lacking self-certainty which was to ignite its desire for self-certainty at the very beginning of the story of the experience of self-consciousness. In contrast to the previous state however, the subject meanwhile knows that it is not alone in the world and that it cannot realise itself as a solitary 'I'. For the subject, this relapse into a state of lack is thus connected to the experience of a painful loss, as it falls out of the world in which it had already found a place. In the vocabulary that we have developed with the help of Hegel's theory of recognition, we are now in a position to reformulate symbolic harm in three distinct ways: as dissolution of the social existence of the subject, as disruption of its self-relation, and as doubt about its own self-conception.

The extent to which doubt about one's own self-conception can become an existential danger can be measured by a Hegelian reading of René Descartes' Meditations on First Philosophy. Descartes famously begins this project by raising a radical doubt, suspending all opinions that seem even slightly questionable. This process goes so far that Descartes even questions his own existence. Like Hegel's Phenomenology, the Meditations are at first set out as a project to find self-certainty, but unlike the Phenomenology, the question is not "Who am I?" but instead the existential question, "Do I exist at all?". Now we know that the point at which Descartes' doubt turns into certainty is the seemingly irreducible cogito ergo sum. With this proposition Descartes thinks he has found the Archimedean point from which his own existence as well as that of the surrounding world can be proven. But we also know that at this point Descartes has only proven the existence of his res congitums. This cer- 
tainty is not sufficient to also gain certainty of himself as res extensa. To do this, he introduces the idea of God in a second step. It is God that ensures the subject that it has a physical manifestation through which it finds itself in the world. The certainty of his own physical existence that Descartes seeks is thus in the end not secured by his own 'I,' but is dependent, rather, upon that singular and absolute other that he calls God. Now if at this point we make a jump from Descartes' argument to Hegel's, it becomes clear that Hegel lets the secular other take the place that Descartes attributed to the absolute other. By means of his recognition, the secular other secures the existence of the subject in the world. And when this recognition is lacking, the subject is thrown back to the sole truth of his cogito. It knows of its own existence, but it cannot be sure whether it also exists in the world. Thus, the lack of recognition is experienced by the subject as a threatening loss of its worldly self-certainty. So from Hegel's perspective, the Cartesian subject can ultimately only overcome its doubt regarding its own existence, by knowing itself to be recognized by an other. Otherwise it finds itself in the precarious state that Descartes, at the beginning of his first meditation, describes as a waking dream. In this state the subject doubts whether it exists in the world surrounding it or whether it is in a state of invisibility, wandering around as a bodiless manifestation.

It is precisely this state of invisibility that is often used in contemporary social philosophical discourse to describe exclusion from social processes of recognition. Many people experience the refusal of recognition as a threat to their visibility in the surrounding lifeworld. ${ }^{23}$ Returning to our first question as to what constitutes the specific quality of hurt or harm caused by disrespect, we are now in a position to propose the following answer: while physical violence aims to inflict bodily harm, symbolic violence aims to bring about the disappearance of subjectivity. When we understand the life-and-death struggle as an occurrence of disrespect, what is therefore at stake is not primarily the physical life of the protagonists, but rather the subject's "being in the world." What Hegel thus wishes to show us with the transition from the struggle to the relation of lord and bondsman is that the emergence of this relation results from the fear of losing this being in the world. The "absolute lord," before whom the subservient consciousness trembles, represents in my reading not so much the fear of physical death as the fear of social death. Insofar as the bondsman has experienced this social death when through the killing of the other he was left without recognition, he was already confronted with the state that Hegel described fittingly with the words: "In that experience it undergoes an internal dissolution, has trembled in every fibre of its being, and everything

23. This point has been taken un most recently by Honneth 2001. Using the example of Ralph Ellison's 1952 novel The Invisible Man, Honneth makes it clear that gestures of provocation sometimes aid those who are socially excluded to achieve at least some form of visibility. Even if such provocations are mostly answered with disrespecting sanctions, they are still important for thos concerned, because through them a minimal degree of visibility can be achieved solid and stable has been shaken to its foundations" (117, translation modified). The experience of the dissolution of one's own existence that Hegel presents here is nothing else than the transition to an experience of social in visibility, which results from the loss of any and all forms of self-certainty.

(iii) The threat of social death forms the starting point from which, in a final step, I would like to describe the social dynamic of disrespect in the lord/bondsman-relationship. Following this dynamic it can be made plausible why the bondsman binds himself step by step further to the disrespect of the lord up until the point of complete identification. This process has three stages, which we can call acceptance, admission, and acquisition. Let us first consider acceptance: the reason why a subject sometimes accepts disrespect is that before it risks dying a social death, it will rather accept that minimal form of recognition still present in an insult. Even potentially harmful words like "you're nothing but a bondsman!" still contain a minimal degree of recognition, because even an utterance that asserts its addressee is no-one is still addressed to someone, who is told that he is no-one. This "paradox of humiliation" is based upon the fact that even those speech acts that claim to deny the humanity of the addressee are directed towards a human being and thus appellatively confirm the very thing they semantically deny. ${ }^{24}$ Even if disrespect does not allow one to maintain one's own individual conception of self, it does at least allow a subject to hold on to the elementary form of self-conception that consists in the fact of being a human being. This form of confirmation entails that we should not understand recognition and disrespect as polar opposites, but rather conceive them as two sides of one and the same process. It is not the case that disrespect begins where recognition ends, but that recognition forms the condition of the possibility of disrespect. The reason why we sometimes accept harmful words is thus simply that these are acts of disrespectful recognition, and as such have the power to save us from social death in that they concede us at least some form of existence in the world.

The second level of the dynamic in the lord/bondsman-relationship can be described as a process of admission. This starts from the premise that most cases of disrespect not only provide an elementary form of recognition, but that beyond they also contain an attribution. In our case this means that the insult "you are nothing but a bondsman!" not only disputes the self-conception of the addressee, but at the same time attributes the addressee a new form of self-conception for which it offers appreciation. To the degree that the insult denies the subject recognition of its already existing conception of self, it opens a new horizon in which the subject could achieve self-certainty. The decisive

"Avishai Margalit formulates the 'paradox of humiliation' with refierence to the lord/hondsmanrelationship as follows: "lumilation typically presupposes the humanity of the humilated. Humi-

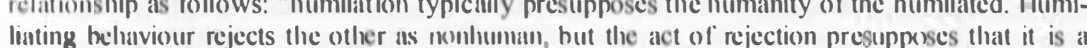

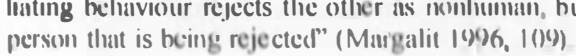


element in this process is that the new self-conception offered is for the mos part one that is considered socially inferior so that the subject concerned cannot find itself again in it. This is because an act of disrespect is always connected to a social displacement, in which a 'higher' conception of self is exchanged for an 'inferior' one. This knowledge can be traced in the everyday expressions we use to describe such scenarios. With dynamic concepts such as degradation, disparagement, or depreciation, we express precisely that the new self-conception on offer has less social value. And insofar as a subject is forced to take on this new self-conception, it must objectify itself in a social existence that it is actually not willing to take over. ${ }^{25}$ In this case, disrespect can be described as misrecognition of the former social existence of the subject. This entails that the subject is confined in an alien self-conception. The admission of an act of disrespect thus goes along with an alienation in the subject's self-conception. And insofar as the subject is thereby forced to develop itself toward a self-conception in which it cannot find itself, we can also speak of a reification. If the harm caused by the act of disrespect can be described on the one hand as dissolution, disturbance, and doubt, we see here how these moments are transformed into misrecognition, alienation, and reification.

The moment of acquisition forms the third and final stage in the dynamic of lord and bondsman. It consists in the gradual closure of the gap between the subject's own self-conception and the self-conception forced upon it from outside. Insofar as the subject cannot rely on alternative contexts of recognition that support its self-conception, it begins to identify gradually ever more with the self-conception ascribed to it in the act of disrespect. This identification entails that the bondsman acquires step by step the concepts that are at the same time the means of his subjugation. His desire for self-certainty turns into the desire for his own submission. This nexus in the desire of the subject leads to a situation in which the more it strives towards recognition, the more firmly it is chained to its submission. The subject will thereby identify ever more with the act of disrespect "you are nothing but a bondsman!". The submission, in this case, becomes part of the process of subjectivation, so that the inferiority is accepted and the lord's contempt toward it internalized to the point of selfcontempt. ${ }^{26}$ It is not seldom that this form of acquisition results in paralysing self-hate, which not only leads the subordinated subject to continually characterise itself with pejorative expressions ("I am nothing but a lowly bondsman")

\footnotetext{
${ }^{25}$ Using a reconstruction of John Austin's theory of speech acts, Judith Butler has explored the social conditions that could make such a takeover necessary (Butler 1997).

${ }^{26}$ Charles Taylor describes this process as follows: "Nonrecognition or misrecognition can inflict (C) f heing" (Taylor 1992, 25). And as regards African Americans, he cites in agreement: "An an " heng" (Taylo ogous point has heen made in relation to hack. that white society has for generations projectud a demeaning image of hem, which some of hem have heen unahle to resist adoping. Their ow self-depreciation, on this view, becomes one of the most petent instruments of their own oppression" (ibid., 26)
}

but also prevents it from defying the disrespect shown toward it. Through defiance it would revolt against the very framework of recognition that secures the certainty of its own existence. On the basis of this moment of acquisition we can thus understand the stability of the relationship of lord and bondsman to the effect that overcoming this relationship would require questioning exactly those conditions that bring the subject into being in the first place. Hegel's presentation of the story of the development of self-consciousness in the Phenomenology, which in the classical reading is interpreted as a continual progressive process, thus appears in a different light. Here one sees clearly the extent to which the dependency on recognition can set in motion a social dynamic of disrespect that leaves the subject with - to conclude with a word from Adorno a 'damaged life.'

Translated by Anita Mage and Alice Lagaay

\section{References}

Brandom, Robert. "The Structure of Desire and Recognition. Self-consciousness and Self-constitution.” In: Philosophy and Social Criticism 33.1 (2007) 127-50.

Butler, Judith. Subjects of Desire, Hegelian Reflections in Twentieth-Centur France. New York: Columbia University Press, 1987.

- "Stubborn Attachment, Bodily Subjection. Rereading Hegel on the Unhappy Consciousness." In: idem. The Psychic Life of Power. Theories in Subjection. Stanford: Stanford University Press, 1997, 31-62.

- Excitable Speech. A Politics of the Performative. New York and London Routledge, 1997.

Descombes, Vincent. Modern French Philosophy. Trans. by L. Scott-Fox and J. M. Harding. Cambridge and New York: Cambridge University Press, 1980.

Gadamer, Hans-Georg. Hegel's Dialectic: Five Hermeneutical Studies. Trans. by P. Christopher Smith. New Haven and London: Yale Universty Press, 1976.

Habermas, Jürgen. "Hegel's Concept of Modernity." In: idem. The Philosophical Discourse of Modernity. Twelve Lectures. Trans. by Frederick G. Lawrence. Cambridge: MIT Press, 1990, 23-45.

Ilegel, Georg Willhelm Friedrich. Phenomenology of Spirit. Trans. by A.V. Miller. Oxford: Oxford University Press, 1977 [1807].

- Encyclopaedia of the Philosophical Sciences, Philosophy of Mind. Trans. by William Wallace and A.V. Miller. Oxford: Oxford University Pres, 1971 | 1830| 
Hobbes, Thomas. Leviathan. Oxford: Oxford University Press, 1996 [1951]. Honneth, Axel. The Struggle for Recognition. The Moral Grammar of Social Conflicts. Trans. by Joel Anderson. Cambridge, Mass.: Polity Press, 1995.

— "Invisibility. On the Epistemology of 'Recognition'." In: Proceedings of the Aristotelian Society - Supplementary Volumes 75 (2001), 111-39.

- "Von der Begierde zur Anerkennung. Hegels Bcgründung von Selbstbewußtsein." In: Klaus Vieweg and Wolfgang Welsch (eds.). Hegels Phänomenologie des Geistes. Ein kooperativer Kommentar zu einem Schlüsselwerk der Moderne. Frankfurt am Main: Suhrkamp, 2008, 187-204.

Kojève, Alexandre. Introduction to the Reading of Hegel. Lectures on the Phenomenology of Spirit. Trans. by James H. Nichols. Ithaca: Cornell University Press, 1980 [1947].

Lacan, Jacques. "The Mirror Stage as Formative of the / Function" [1949]. In: idem. Ecrits, A Selection. Trans. by Bruce Fink et al. New York and London: W.W. Norton and Company, 2002, 75-82.

Margalit, Avishai. The Decent Society. Trans. by Naomi Goldblum. Cambridge: Harvard University Press, 1996.

Markell, Patchen. Bound by Recognition. Princeton: Princeton University Press, 2003.

Neuhouser, Frederick. "Deducing Desire and Recognition in the Phenomenology of Spirit.” In: Journal of the History of Philosophy 24.2 (1986), 243-62.

- Foundations of Hegel's Social Theory. Actualizing Freedom. Cambridge: Harvard University Press, 2000.

- "Desire, Recognition, and the Relation between Bondsman and Lord" In: Kenneth Westphal (ed.). The Blackwell Guide to Hegel's Phenomenology of Spirit. Malden, Mass.: Wiley-Blackwell, 2009, 37-54.

Peperzak, Adrian T. "Hegel and Hobbes revisited." In: Ardis Collins (ed.). Hegel on the Modern World. Albany: Suny Press, 1995, 199-217.

Pinkard, Terry. Hegel's Phenomenology. The Sociality of Reason. Cambridge: Cambridge University Press, 1994.

Pippin, Robert. Hegel's Practical Philosophy. Cambridge: Cambridge University Press, 2008

Redding, Paul. "The Independence and Dependence of Self-Consciousness: The Dialectic of Lord and Bondsman in Hegel's Phenomenology of Spirit." In: Frederick C. Beiser (ed.). The Cambridge Companion to Hegel and Nineteenth-Century Philosophy. Cambridge: Cambridge University Press, 2009, 94-111.

Ricœur, Paul. The Course of Recognition. Trans. by David Pellauer. Cambridge: Harvard University Press, 2005.

Roth, Michael S. Knowing and History. Appropriations of Hegel in TwentiethCentury France. Ithaca: Cornell University Press, 1988

Sartre, Jean-Paul. Being and Nothingness. A Phenomenological Essay on On- tology. Trans. by Hazel E. Barnes. New York: Washington Square Press, 2002 [1943].

Siep, Ludwig. "Der Kampf um Anerkennung. Zu Hegels Auseinandersetzung mit Hobbes in den Jenaer Schriften." In: Hegel-Studien 9 (1974), 155-207.

Tamineaux, Jacques. "Hegel and Hobbes." In: idem. Dialectic and Difference. Modern Thought and the Sense of Human Limits. Ed. by Robert Crease and James D. Tecker. Atlantic Highlands: Humanities Press, 1985, 1-37.

Taylor, Charles. Hegel. Cambridge and London: Cambridge University Press, 1975.

- Multiculturalism and "The Politics of Recognition." Princeton: Princeton University Press, 1992.

Williams, Robert R. Hegel's Ethics of Recognition. Berkeley and Los Angeles: University of California Press, 1997. 


\title{
Destruction in the Performative
}

\section{Critical Studies}

Vol. 36

General Editor

Myriam Diocaretz

Tilburg University

\section{Editorial Board}

Anne E. Berger, Cornell University

Rosalind C. Morris, Columbia University

Marta Segarra, Universitat de Barcelona

\author{
Edited and with an introduction by
} Alice Lagaay and Michael Lorber

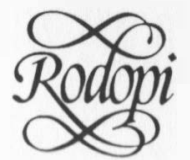




\section{Foreword \& Acknowledgements}

Cover Image by Miika Ahvenjärvi

\section{Cover Design by Inge Baeten}

The paper on which this book is printed meets the requirements of "ISO 9706: 1994, Information and documentation - Paper for documents -

ISBN: 978-90-420-3457-0

E-Book ISBN: 978-94-012-0741-6

CEditions Rodopi B.V., Amsterdam - New York, NY 2012

Printed in the Netherlands
What do G.W. Hegel's dialectics of recognition, Luk Perceval's theatrical staging of Penthesilea, a French politician's hunger strike and Richard Serra's sculptures for urban space all have in common? They can be described as pertaining to various interconnected modes of destructive dynamics within a performative paradigm. Performativity is conceived here as a multi-faceted concept used to grasp and connect phenomena from different contexts on a spectrum ranging from language and social theory to drama and theatrical practice, from aesthetics and cultural science to economics and process theory. In all these realms, what characterises the performative perspective is a sharpened focus on the material and sensual, i.e. aisthetical character of events, and on the reality-constituting power of human actions and processes. Theoretical approaches informed by performative theories do not take for granted, in an essentialist sense, what lies before and around us as the world, but strive to draw attention to the particular manner in which that world is constituted in its very multi-dimensionality by human activities, processes, events and, above all perhaps, by perspectives. In recent years, the performative paradigm has had a profound influence on theory in the humanities and has led, broadly speaking, to a heightened understanding of the general interrelatedness of human realities. This emphasis has resulted, however, in something of a bias towards, on the one hand, positive phenomena and positively connotated metaphors to describe those phenomena, such as "action," "productivity" and "presence," "voice," "embodied language," "actualisation," "event-ness" and "materiality." On the other hand, the focus on the creation and interrelation of human realities has tended to overlook the often simultaneous destructivity involved in those processes.

In response to this bias, there have been increasing moves in recent years to investigate the boundaries of the seemingly activist and generativist performative tendency. This is a drive to uncover, as it were, the "flipside" of performativity by addressing not just the positive phenomena of human action, production, language and presence, but also the negative counterparts of these, as in for example "inoperativity," "restraint," "absence" and "silence." Moreover, first steps have been taken to investigate both the productive effectiveness of these various modes of action and phenomena, and the destructive dimension involved in all.

This volume is the result of a three-year interdisciplinary research focus group (2008-2010) dedicated to "Destructive Dynamics and Performativity" within the Collaborative Research Centre "Performing Cultures" (Sonderforschungshereich 'Kulturen des Performativen') at the Freie Universität Berlin. 
The particularity of this volume is that it does not simply present a selection of papers that have been commissioned by the editors on a particular theme, but that it presents the results of a group of researchers who, from various disciplinary backgrounds, met together to discuss and collaborate on the theme of destructivity. The individual articles in this volume are thus shaped and informed by the many discussions we held. We are grateful to all the members of the focus group "Destructive Dynamics and Performativity" for the lively and inspiring debates held there: to Hartmut Böhme, Leena Crasemann, Robert Felfe, and Barbara Gronau; to Kristiane Hasselmann, Steffen K. Herrmann, Elke Koch, Hannes Kuch, Renate Lorenz and Robert Schmidt; to Jenny Schrödl, Sabine Schülting, Andrea Sieber and Kirsten Wagner; to Rebecca Wolf, Volker Woltersdorff, and Ulrike Zellmann. We also extend our thanks to the guest speakers who inspired and contributed to our discussions: Reinhold Görling, Vinzenz Hediger, Linda Hentschel, José E. Muñoz and Joseph Vogl, as well as to Nikita Dhawan and Katja Rothe for kindly accepting the invitation to contribute to this volume. Our heartfelt thanks go to Erika FischerLichte, chairwoman of the Collaborative Research Centre, for encouraging and supporting this research.

We gratefully acknowledge the valuable work of the team of competent and dedicated translators, Anita Mage, Laura Radosh, Gratia Stryker-Härtel, and Kate Sturge, as well as Christian Struck's part in preparing the manuscript. Finally, we are most grateful to Esther Roth and the editorial board at Rodopi for their helpful comments and the enthusiasm they have brought to this project. It has been a pleasure preparing this volume with them.

Alice Lagaay \& Michael Lorber

Berlin, July 2011

\section{Table of Contents}

Alice Lagaay and Michael Lorber

Introduction: Destruction in the Performative

\section{Language, Music, Noise}

Steffen K. Herrmann

Recognition and Disrespect: Lordship and Bondage

in Hegel's Phenomenology of Spirit

Nikita Dhawan

Hegemonic Listening and Subversive Silences:

Ethical-political Imperatives

Rebecca Wolf

Two Saints and the Power of the Auditive

Jenny Schrödl

Acoustic Violence in Contemporary German Theatre

\section{Embodiment, Identity, Ecstasy}

Barbara Gronau

Asceticism Poses a Threat: The Enactment of Voluntary Hunger

Renate Lorenz

Salomania - Trans and Trans-temporal: A Queer Archaeology

of Destructiveness

Volker Woltersdorff

Masochistic Self-shattering between Destructiveness

and Productivity 


\section{Things, Spaces, Networks}

Kristiane Hasselmann

Triggering Latency Zones in Modern Society:

Richard Serra's Sculptures within the Urban Setting

Katja Rothe

Creative Destructions: Gabriel Tarde's Concept

of a Passionate Economy

Robert Schmidt

Code Decay: Organizational Performance

and Destructivity

List of Contributors

\section{Introduction: Destruction in the Performative}

\author{
Alice Lagaay and Michael Lorber
}

Cultural transformation tends to be described in one of two ways: either with reference to what comes about, is created or emerges in the process of change, or with reference to what is destroyed or obscured in that process. Within a performative paradigm, that is, from a perspective that focuses on the manner in which social and cultural reality is constituted or brought about by human activity, theorists have tended to underline the productive aspects of transformation by emphasising the creative thrust of performative processes and events. In so doing, this perspective has tended to overlook the extent to which a certain destructive element may in fact be inherent to such performative processes.

Within the realm of cultural studies, there have been recent calls for, and some preliminary steps taken towards contouring, a new "theory of destruction" to meet - and to some extent to counter - what have been broadly identified as the dominant discourses of innovation, creativity and emergence (e.g. Alan Liu, 2009). The present volume answers that call, albeit within a particular context of its own. It seeks to explore the manner in which destructivity such as the destabilisation and destruction of orders, subjects and bodies can be grasped by concepts of performativity. In other words, to what extent may a certain destructive dynamic be inscribed within the very notion of performativity?

Performativity, as understood here, is rooted in a variety of theoretical perspectives combining linguistic, cultural-sociological as well as aesthetic concerns, all of which are of relevance for a multitude of different disciplines. Firstly, the concept refers back to John L. Austin's speech act theory and his analysis of the manner in which language can be shown to be not just simply a medium of human expression, not just used, that is, to describe an event or a reality that is external to it, but that its very utterance can bring about a transformation of reality (cf. Austin 1962; Searle 1969). Secondly, the concept relates to Judith Butler's notion of the performative constitution of (gender) subjectivity by means of ritualised linguistic iteration and culturally prescribed patterns of behaviour (e.g. Butler 1993). Furthermore, the concept incorporates a more general reference, drawn from a theatrical and anthropological context, to the embodied practices and socially encoded ritualised events 